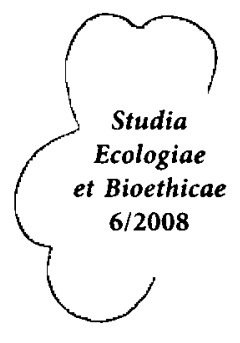

\title{
Rola tradycji w procesie zacieśniania więzi etnicznej Łemków (druga połowa XIX - początek XX wieku)
}

Wszystkie społeczeństwa niezależnie od stopnia rozwoju historycznego wykorzystują dorobek i osiągnięcia poprzedzających je pokoleń. Proces przekazywania treści kulturowych posiada jednak szczególne znaczenie w tradycyjnych zbiorowościach agrarnych. Przekaz odbywać się może albo za pośrednictwem mowy i innych dźwięków (np. muzyki) oraz pokazów czynności i przedmiotów dostrzegalnych wzrokiem, albo też może polegać na tzw. zasadzie styczności pośredniej, to jest „bezosobowej" metodzie opierającej się na wykorzystywaniu takich "narzędzi” utrwalających ludzkie myśli jak pismo, druk, nuty, czy fotografia ${ }^{1}$. Przywiązanie emocjonalne do pewnych treści wyznaczała najczęściej świadomość ich dawnego pochodzenia, co powodowało, że ludność traktowała wartości kulturowe w kategoriach „sacrum” - jako rzecz świętą.

Zmiany zachodzące w XIX w. prowadziły do przekształcania się kultury chłopskiej, jednak nie wywołały przemian w sferze świadomości. Dzięki temu dawne wartości były nadal cenione i pełniły dotychczasowe funkcje. Emocjonalne przywiązanie do wszelkiej spuścizny opierało się na przekonaniu o dużej efektywności dawnych wzorów, co odgrywało istotną rolę w preferowaniu starych, tradycyjnych metod gospodarowania czy uprawy roli². $Z$ powyższymi prawidłowościami ściśle wiąże się problem funkcjonowania jednego $z$ głównych czynników procesów świadomościowych jakim jest tradycja. Encyklopedia Powszechna podaje, iż tradycją są "przekazywane z pokolenia na pokolenie treści kulturowe (obyczaje, poglądy, wierzenia, sposoby myślenia i zachowania, normy postępowania, itp.) wyróżnione przez daną zbiorowość na podstawie określonej hierarchii wartości z całokształtu dziedzictwa kulturowego jako społecznie doniosłe dla teraźniejszości lub przyszłości". Dalej stwierdza, że „tradycja jest jednym z głównych sposobów włączania przeszłości i jej treści kulturowych do aktualnej świadomości społecznej i stanowi zasadniczy ele-

1 K. Doвrowolski, Studia nad życiem spotecznym i kulturą, Wrocław 1966, s. 81-82.

2 R. Томіскі, Tradycja i jej znaczenie w kulturze chlopskiej, „Etnografia Polska” 1973, t. 17, z. 2, s. 48 . 
ment procesów świadomościowych"3. Równie szeroko pojęcie „tradycji” rozumie Kazimierz Dobrowolski twierdząc, iż jest to „wszelka spuścizna, którą ustępujące generacje przekazują pokoleniom wchodzącym w życie"4.

Ryszard Tomicki przy definiowaniu tradycji uwzględnił sferę życia psychicznego spoleczności twierdząc, że: „tradycją danej grupy społecznej jest ta część dziedzictwa przekazywanego drogą transmisji ustnej i pokazu, której przejmowaniu towarzyszy świadomość jej pochodzenia z przeszłości, która jest przez grupę afirmowana i stanowi obiekt emocjonalnego przywiązania wyrażającego się w przekonaniu o jej wartości i niemożności zmiany bez istotnych konsekwencji negatywnych dla grupy, bądź jednostek". W związku z takim rozumowaniem tradycyjną kulturę chłopską określił jako „wytwór tych społeczności, w których tradycja stanowiła czynnik sterujący większością dziedzin życia wiejskiego"s.

$\mathrm{Na}$ rolę tradycji w umacnianiu poczucia wspólnoty grupowej zwrócił uwagę także Stanisław Ossowski. Uważał on, iż więź społeczna wytwarza się samorzutnie w ciągu wielu lat współżycia. O mocy tej więzi decyduje „wspólny kapitał przeżyć” stanowiący pewną część tradycji.

Problematyką tradycjonalizmu, podczas badania procesów narodotwórczych w Europie Środkowo-Wschodniej, zajął się również Józef Chlebowczyk. Zauważył on, iż społeczność wiejska okresu przedindustrialnego była mało aktywna i mało mobilna. Nie nawiązywała kontaktów z szerszym światem (prócz takich wyjątków jak np. służba wojskowa). W odosobnionym środowisku wiejskim panował konserwatyzm obyczajowy, uprzedzenie i nieufność do wszystkiego co „obce” i nowe. Pogłębiało to więź „swojskości”, na której treść składały się związki pokrewieństwa oraz współżycie sąsiedzkie. Te związki odgrywać miały zasadniczą rolę w kształtowaniu poczucia odrębności, podczas gdy przedziały językowe czy gwarowe jedynie pogłębiały to poczucie. Wyżej wymienione czynniki wpływały na powstanie patriotyzmu lokalnego. Patriotyzm tego typu tracił swój pozytywny charakter w momencie uświadomienia sobie przez zbiorowość posiadania tych samych wspólnych cech kulturowych z szerszą społecznością .

Badacze zajmujący się regionem Łemkowszczyzny twierdzą zgodnie, że jej agrarna, konserwatywna społeczność przywiązana była mocno do obyczajów, wierzeń oraz charakterystycznych dla siebie poglądów i zachowan. Bez wątpienia niemały wpływ na funkcjonowanie przez długi czas tradycyjnej kultury miała izolacja terytorialna, która skutecznie chroniła Łemkowszczyznę przed wpływami z zewnątrz.

Pierwotne więzy wytworzone przez wspólne bytowanie określone były przez charakter współżycia sąsiedzkiego rządzącego się określonymi prawami. Zgodnie

\footnotetext{
Encyklopedia Powszechna PWN, Warszawa 1976, t. 4, s. 475.

K. Dobrowolski, Studia nad życiem spolecznym...op. cit., s. 35.

R. Томіскі, Tradycja i jej znaczenie... op. cit., s. 49.

J. Chlebowczyк, Procesy narodowotwórcze we wschodniej Europie środkowej w dobie kapitalizmu (od schyłku XVIII do poczq̨tków XX wieku), Kraków 1975, s. 71-72.
} 
$z$ decydującym nieraz o przetrwaniu grupy prawem solidarności wewnętrznej każdy, kto znalazł się w szczególnej potrzebie w życiu osobistym czy gospodarczym mógł liczyć na pomoc sąsiedzką. I tak pomagano sobie przy żniwach, sianokosach, czy wykopkach ziemniaków. Jeśli nie kończono pracy w dzień kontynuowano zajęcia do późnej nocy, nazywając je wtedy „lampażem” (od okrągłej stajennej lampy naftowej). Pracy zawsze towarzyszył śpiew, a gospodyni częstowała pomagających specjalnie przygotowanymi potrawami takimi jak zrazy, ryż, mleko ${ }^{7}$. Wspólne wykonywanie pracy i spożywanie posiłków znacznie zacieśniało więzi sąsiedzkie, a w dalszej perspektywie także grupowe.

Łemkowie żyli dość ubogo. Rolnictwo stało na niskim poziomie, szałaśnictwo występowało jedynie w Beskidzie, a bydło wypasano sezonowo. Wiosną udawano się w dalekie wędrówki w okolice Tucholi, na Huculszczyznę, czy w góry Marmaroszu, gdzie zakupywano bydło i owce. Jesienią zaś podhodowane zwierzęta sprzedawano na jarmarkach (np. w Lutowiskach). Niektórzy znani owczarze okresu międzywojennego Filko z Królika, Wanio Semaniw z Tarnawki, Onufrij Bejmuk z Łabowej i inni z Uścia Ruskiego (dzisiaj: Uście Gorlickie) oraz Żdyni udawali się co roku do Siedmiogrodu, gdzie wspólnie zakupywali setki owiec, przeganiając je następnie do Pilzna, Tuchowa, Tarnowa lub nawet dalej na Śląsk ${ }^{8}$.

Ważne źródło dochodu na Łemkowszczyźnie stanowiły zawody wędrowne, co odbiegało od wyobrażeń na temat braku mobilności tradycyjnych społeczeństw wiejskich. Handel mazią, z którego słynęła wieś Łosie ściśle wiązał się z eksploracją dalekich terenów. Szlaki handlowe maziarzy sięgały odległych miast AustroWęgier, Kongresówki i Rosji ${ }^{9}$. Na podobne wyprawy udawali się również druciarze z Rusi Szlachtowskiej ${ }^{10}$. Z długimi wędrówkami wiązał się również handel owocami. Łemkowie z okolic Wielkiego Wisłoka, Surowicy, Olchowej, Tychani, Grabu, Tylicza i Muszyny udawali się na Węgry, gdzie zakupywali wczesne owoce; winogrona, truskawki, jabłka... Sprzedawali je następnie we dworach czy w miastach np. Bochni i Krakowie ${ }^{11}$. Bywało, że wspólne wędrówki zacieśniały więzi pomiędzy ich uczestnikami, co przejawiało się choćby we wzajemnej pomocy w czasie podróży. Jednak społeczne współdziałanie w zawodach wędrownych wystąpiło zaledwie $\mathrm{w}$ formie zaczątkowej. We wsiach będących ośrodkami tego typu profesji wytworzyły się na tle majątkowym arystokratyczne grupy, izolujące się od reszty społeczności wiejskiej. Wyższy stan majątkowy akcentowały one odmiennym, często miejskim strojem, sposobem bycia, porozumiewania się czy też wprowadzaniem innowacji w zakresie budownictwa. Wędrówki poza „swoim” obszarem (tu: Łemkowszczyzną) nie wpływały

\footnotetext{
J. FAlKowski, B. PASZnYCKI, Na pograniczu lemkowsko-bojkowskim, Lwów 1935, s. 28.

J. TARnowycz, Ilustrowana istorija Lemkiwszczyny, Lwów 1936, s. 43.

9 Por. M. BrylaK-Zakuska, Maziarska wieś Łosie, Kraków 1983; W. Piątkowski, Maziarze, „Magury" 1987, s. 3-8.

10 A. Ostrowińska, U Rusinów przed pólwieczem. Etnografia Rusi Szlachtowskiej, „Magury” 1986, s. $122-136$.

1 J. TARNOWYCZ, Ilustrowana istorija..., op.cit., s. 42.
} 
w żaden sposób na zacieśnienie więzi z nowym terytorium, bowiem jawiło się ono jako „obce”; przejmowano najwyżej poszczególne elementy dorobku kulturowego. Wykonywanie zawodów wędrownych spowodowało dodatkowe rozwarstwienie społeczności wiejskiej („dodatkowe”, ponieważ wcześniej też istniały podziały o charakterze socjalnym np. biedota wiejska - chłopi zamożni) i przyczyniło się do wytworzenia silnego poczucia wspólnoty członków nowo powstałych grup zawodowych ${ }^{12}$. Większy wpływ na podtrzymywanie więzi grupowej wśród Rusinów Łemkowszczyzny posiadało poczucie wspólnoty kształtujące się na przesłankach religijnych ${ }^{13}$. Religijność Łemków ujawniała się żywym, wręcz teatralnym, zachowaniem na nabożeństwach w cerkwi, stawianiem trójramiennych krzyży, kapliczek i figur przydrożnych (słynne prace kamieniarzy ze wsi Bartne pow. Gorlickiego), tłumnym udziale na odpustach oraz pozdrowieniach religijnych. Cerkwie budowano zgodnie $z$ wymogami liturgii bizantyjsko-słowiańskiej stworzonej na terytorium Rusi Kijowskiej i Halicko-Wołyńskiej. Modlono się przed ikonami, na których umieszczano świętych patronów Rusi ${ }^{14}$.

Życie religijne Łemków zorganizowane było w podstawowych jednostkach jurysdykcyjnych, które tworzyły parafie. $W$ ich ramach obchodzono ważniejsze święta. O wspólnym świętowaniu ważniejszych uroczystości świadczyć może list nadesłany z Dynowa do redakcji „Zori Halickiej” w 1850 r., z którego dowiadujemy się o uroczystym obchodzeniu czwartej rocznicy zniesienia pańszczyzny w Galicji. Prócz Dynowa uroczystość likwidacji pańszczyzny świętowały także wsie położone w okolicy Dubiecka. Mieszkańcy Ruskiego Sioła, chcąc uczcić jubileusz, zaprosili "swojego" księdza oraz dwóch duchownych z pobliskich miejscowości, by wspólnie odprawili uroczyste, dziękczynne nabożeństwo ${ }^{15}$. W wyżej podanym przypadku inicjatwa wspólnego świętowania wypływała od ludności wiejskiej, pragnącej dzielić radość świętowania z członkami podobnych im kulturowo wsi sąsiednich, co także wzmacniało poczucie wspólnoty grupowej.

Wyraz łączności z tradycją Rusi Kijowskiej dali Łemkowie podczas świętowania jubileuszów przyjęcia chrztu w Kijowie (988). Szczególnie uroczyście obchodzono 950 rocznicę tego wydarzenia. Greckokatolickie biskupstwo w Przemyślu powołało specjalny Komitet Święta Chrześcijańskiej Ukrainy oraz ogłosiło Jubileuszowy Rok na okres $14.08 .1937-14.08 .1938^{16}$. Jego otwarcie poprzedziły uroczystości związa-

12 Por. M. BRylaK-ZAŁusKa, Maziarska wieś Łosie, Kraków 1983.

13 Na ważną rolę religii spajającej społeczność łemkowską zwrócono uwagę w „Karpatorusskim Kalendarzu” ( Nowy York 1955): „Cerkiew w Ropkach wybudowana byla ok. 320 lat temu, bylo (tam- B.W.) wtedy 23 gospodarzy. Kiedy stawiano cerkiew przyszli im $z$ pomocą hańczowianie i wysowianie" (czyli mieszkańcy pobliskich wsi).

14 W. Mokry, Rusini - Łemkowie - Ukraincy, „Tygodnik Powszechny” 1984, nr 45.

15 „Zoria Hałyćka”, 1850, nr 41, s 25.

16 Biskupem przemyskim w tym czasie był pochodzący z Lemkowszczyzny Josafat Kocyłowski zeslany po wojnie przez sowieckie władze na Syberię. 
ne z obchodzeniem uroczystości św. Olgi i Włodzimierza oraz rekolekcje, okazjonalne kazania, koncerty i akademie. Kamienne, jubileuszowe krzyże wznoszono 27 września 1938 r., w dniu obchodzenia uroczystości Podniesienia Św. Krzyża ${ }^{17}$. Umieszczano na nich okolicznościowe napisy cyrylicą np.: Juwitej kreszczeniji Rusy 988-1938. We wsi Wola Michowa (pow. leski) wzniesiono, mimo uprzednich sporów, krzyż odwołujący się do poczucia wspólnoty z Ukrainą (nie Rusią jak w innych przypadkach), który zawierał okolicznościowy napis: 950 littja Kreszczenija Ukrajiny ${ }^{18}$.

Jak istotna była sfera rzeczywistości religijnej dla Łemków wskazuje choćby tzw. sprawa Anny Burczak, które dało początek wprowadzenie zakazu posługiwania się pozdrowieniem religijnym Sława Isusu Chrystu („Niech będzie pochwalony Jezus Chrystus") w szkole podstawowej w Jaworkach. Anna Burczak (1936 r.) pouczyła swoją córkę, Marię, aby wbrew decyzji miejscowych władz szkolnych używała tej formy powitania. W ostateczności Marię Burczak oskarżono o sprzeciwienie się woli nauczyciela oraz skazano sądownie na 3 miesiące aresztu. Po odwołaniu się do Sądu Okręgowego w Nowym Sączu uczennica została uniewinniona, a szkolny inspektor z Nowego Targu uchylił rozporządzenie nauczyciela ${ }^{19}$.

Wśród ludności łemkowskiej żywa była tradycja miejsc świętych. Dużą rolę odgrywały zatem pielgrzymki, będące istotnym czynnikiem integrującym w ramach wykraczających poza granicę parafii (przykładowo wierni parafii tylawskiej i świątkowskiej udawali się na pielgrzymki aż do Kijowa). Każde ważniejsze wydarzenie w rodzinie: chrzest, wesele, choroba, pogrzeb ściśle łączyło się z uroczystościami cerkiewnymi. Łemkowie bardzo dbali o to, by przebiegaly one zgodnie $z$ tradycyjnym systemem magiczno-religijnym, ponieważ - jak wierzono - niespełnienie pewnych ceremonii mogło w przyszłości skutkować jakimś nieszczęściem.

$\mathrm{W}$ uroczystościach rodzinnych uczestniczyła $\mathrm{z}$ reguły większość mieszkańców wsi. Za punkt honoru uchodziło ugoszczenie wszystkich członków społeczności wiejskiej/parafii, co bywało często przyczyną zubożenia całej rodziny i pociągało za sobą konieczność oddania w dzierżawę chaty czy gruntu ${ }^{20}$. Niemniej wspólne obchodzenie świąt rodzinnych zacieśniało więzy grupowe w granicach nie tylko jednej wsi, ale często integrowało szerszą społeczność z innych miejscowości.

Mieszkający w górach Łemkowie, izolowani od wpływów miejskich, dłużej i w pełniejszej formie zachowali stare zwyczaje doroczne. Do najbardziej uroczyście obchodzonych świąt w ciągu roku można zaliczyć Boże Narodzenie (Ridztwo) oraz Wielkanoc (Wełykodeń). Do tych uroczystości Łemkowie przygotowywali się długo i starannie, a ich przebiegowi towarzyszyło wykonywanie licznych praktyk magicznych mających zapewnić zdrowie i szczęście w rodzinie oraz urodzaj w polu. Niektóre zabiegi magiczne odbywały się w kręgu rodzinnym, inne zaś posiadały cha-

17 „Nasz Łemko” 1938, nr 8, s. 2.

18 ibidem, nr 17, s. 8.

19 „Nasz Łemko”, 1936, nr 30, s. 6.

20 J. Falkowski, B. PAsZNYCKI, Na pograniczu... op. cit., s. 13. 
rakter ogólnowiejski. Szczególnie te ostatnie miały istotny wpływ na cementowanie społeczności łemkowskiej. Wspomnieć tutaj można o przebierańcach chodzących od domu do domu z życzeniami i kolędą. Nie ograniczali się oni do penetracji rodzinnej miejscowości, ale w okresach świątecznych odwiedzali mieszkańców innych wsi. Znane są również przypadki, kiedy kolędnicy z terenów nadgranicznych trafiali do wiosek położonych po drugiej stronie granicy - dziesiejszej Słowacji. Z kolędą zwyczajowo związane było zabieranie darów, które niekiedy posiadały formę pieniężną (od początku XX w.). Pieniądze zebrane w czasie kolędy przebierańcy przekazywali na „wyższe cele”. I tak w piątym numerze "Naszego Łemka” z 1936 r. czytamy o chłopcach z Beska, którzy dochód z kolędy przekazali dyrektorowi Koła „Ridnej Szkoły" w Sanoku. Częściej jednak dochód taki wykorzystywany bywał na pokrycie kosztów związanych z utrzymaniem parafialnej cerkwi. Wędrówki „na druhe seło" odbywały się również późną jesienią, kiedy świętowano tzw. weczyrky. Przykładowo Piotr Bołdys z Koniecznej (powiat gorlicki) jako młody chłopak chodził z komediantamy do wsi ruskich, leżących po drugiej stronie granicy ${ }^{21}$. Obok zacieśniania więzi międzywioskowej weczyrky przyczyniły się również do uzmacniania poczucia wspólnoty w granicach jednej wsi. Na te wieczorne spotkania, które pełniły także funkcję spotkań matrymonialnych, przychodziło ok. 20-30 osób przeważnie młodych. Jeśli wieś była duża spotykano się kolejno w kilku chatach. Wykonywanie różnych prac domowych (skubanie pierza, przędzenie, wyplatanie taśm na kapelusze) umilano sobie różnymi zabawami, których większość przekazywana była w niezmienionej postaci z pokolenia na pokolenie, świadcząc o żywym tradycjonalizmie wsi łemkowskich.

Wolny czas wypełniano także opowiadaniem bajek oraz niesamowitych historii o czarownicach i strachach, a cieszący się autorytetem starsi ludzie wspominali o tym, ,jak to kiedyś bywało". Przekazywane podania i legendy stawały się czasem prawdziwą historią społeczności. I tak np. zgodnie $z$ tradycją dawni mieszkańcy wsi Duszatyn zostali wyduszeni przez Tatarów - stąd też nazwa. Podobnie nazwa miejscowości Piekarki miała powstać po bitwie konfederatów barskich z wojskiem, kiedy to zwycięzcy (nie wiadomo kto: konfederaci czy wojsko) spalili pokonanych w piecach. Inne opowieści zaś dowodziły istnienia łączności kulturowej Rusinów Łemkowszczyzny z Rusią Kijowską. Mówiły one o tym, że: „Kiedy szlachta polska zajęła góry, młodzież odważniejsza wyjeżdżała na sicz „kozakowaty” (...) „Stąd wracali (młodzi - B.W.) jako lirnicy czy bandurzyści i grali pieśni ukraińskie"22.

Oprócz weczyrek obrzędowym zwyczajem o charakterze ogólnowiejskim były sobitki tj. sobótki palone $\mathrm{w}$ wigilię św. Jana. Na ten dzień pasterze przygotowywali na wzgórzach wielkie ogniska - watry. W tym czasie w chatach wygaszano piece i lampy, a wszyscy zbierali się na wzgórzach przy płonących ogniach. Chłopcy biegali z głowniami odpalonymi od stosu, skakali przez płomień, śpiewali. Kobiety

21 Z. Cieśla-Reinfussowa, Weczyrky na Łemkowszczyźnie, „Materiały M.B.L. w Sanoku”, Sanok $1981, \mathrm{nr} 2, \mathrm{s.} 88$.

22 S. ZYNYN, Łemkovyna - Sybir, Lwów 1934, s. 10. 
dorzucały do ognisk święcone zioła, by rozchodzący się z nich dym przyniósł urodzaj ${ }^{23}$. Analizując pieśni sobótkowe J. Mroczek zauważył przemożny wpływ melodii słowackich, węgierskich i rumuńskich na ich linię melodyczną oraz stwierdzil, że na Łemkowszczyźnie utrzymały się one w swej pierwotnej postaci zadziwiająco długo, zdecydowanie dłużej, niż podobne pieśni na Rusi Kijowskiej ${ }^{24}$.

Rusini Łemkowszczyzny dzielili się na większe wewnętrzne grupy lokalne. Jednym z objawów podziałów, ale też obyczajowego tradycjonalizmu Łemków było przywiązanie do lokalnych przezwisk, słownictwa oraz specyficznych cech języka. Całe wsie posiadały osobne przezwiska często o charakterze obraźliwym. I tak wieś Prełuki nazywano jatinkami (od używania zamiast słowa tobi - ti; np. ja ti zroblu). Mieszkańców Turzańska przezywano cidylnykami (od cidyly - płóciennej torby żebraczej) $)^{25}$. Innym kryterium podziału stanowiły np. charakterystyczne elementy części stroju huni - samodziałowego płaszcza z dużym, spadającym na plecy kołnierzem. W zależności od jego formy wyodrębniali oni grupy torokarów, swicaków i pupkarów. Niekiedy poczucie odrębności było śladem dawnych stosunków feudalnych. I tak mieszkańcy kresu muszyńskiego nazywani byli biskupianami (od wsi biskupich), podczas gdy Łemkowie znad Osławy określali siebie korolicami (były tam dawniej wsie królewskie). Poczucie odrębności między poszczególnymi wsiami, jak i pomiędzy grupami lokalnymi, nie przeradzało się w skrajne, wzajemne niechęci oraz nie posiadało negatywnego, destrukcyjnego napięcia ${ }^{26}$.

Wszyscy Lemkowie tradycyjnie nazywali siebie Rusinami ${ }^{27}$. O wielkim przywiązaniu do nazwy własnej świadczyć może fakt zastosowania jej do tworzenia nazwisk

${ }^{23}$ J. MaDzIK, Zwyczaje doroczne Łemków, (w:) Nad rzekq Ropą. Zarys kultury ludowej powiatu gorlickiego. Kraków 1965, s. 284.

24 J. Mroczex, Pieśni sobótkowe u Lemków, „Materiały MBL w Sanoku”, Sanok 1966, nr 4, s. 57$-63$.

25 J. Falkowski, B. PAsznYcki, Na pograniczu... op. cit., s. 32.

26 R. ReINFuss, Lemkowie w przeszlości i obecnie (w:) Lemkowie, kultura - sztuka-język, Warszawa - Kraków 1987, s. 15.

27 Zdarza się, że w pewnych okolicznościach język przenika do terminologii, jakiej używa się w nazewnictwie państwa, narodu czy grupy etnicznej. Sytuacja taka zaistniała podczas przyjmowania nazwy: „Lemkowie” przez grupę Rusinów zachodniego regionu Lemkowszczyzny. Miano „Łemkowie” nadane zostało góralom ruskim przez wschodnich sąsiadów, a ukształtowało się pod wpływem używanego przez nich słowa „łem”, „łen” - co oznacza „tylko”, „lecz”. Nowe określenie poczęło przyjmować się pod koniec XIX w. Według A. Kwileckiego i R. Reinfussa po raz pierwszy pojawić się miało w gramatyce języka dla ludności ruskiej wydanej w Galicji przez Osypa Łewyćkiego w 1834 r. Nieco później pod wpływem Łewyćkiego użył nazwy „Łemkowie” J. Šafarzyk w pracy „Słowiańskie starożytności”, która w polskim thumaczeniu ukazała się w 1844 r. Siedem lat później, aczkolwiek $z$ wahaniem, przytoczył ją W. Pol w przypisie do opracowania „Rzut oka na północne stoki Karpat”. Pol wolał jednak nazwy Czuchońców lub Kurtaków powstale od nazwy charakterystycznego stroju noszonego przez ruskich górali (czuha, czuhania, kurta, kurtka). Jego stosunek do określenia: „Łemkowie” odzwierciedlają słowa „(..) wśród właśnie tych górali sanockich, czyli jak ich chcą nazwać Łemków leżą nad Osławą trzy wioski w niewielkiej odległości od siebie, gdzie w jednej mówią „Lem”, w drugiej „nem”, w trzeciej „leż” 
(np. Rusyniak, Rusenko, Rusyn), czy też nazw miejscowości (Korolewa Ruska, Ropica Ruska, Ruska Wola, Ruski Potok, Uście Ruskie). Przywiązanie do nazwy Rusin, ruski było jedną z przyczyn powodujących trudności w przyjęciu przez Łemków nowej nazwy Ukrainiec, ukraiński na początku XX wieku.

Tradycjonalizm Rusinów Łemkowszczyzny przejawiał się również w sferze kultury materialnej. Jeszcze $w$ drugiej połowie okresu międzywojennego można było zobaczyć na targach Rusinów łemkowskich ubranych w stroje ludowe. Specjalnie dobrze zachowały się stroje kobiece, które do II wojny światowej były noszone zarówno do pracy jak i w czasie świąt. Ubiór tradycyjny wśród Łemków utrzymał się znacznie dłużej i lepiej niż na Pogórzu. Spowodowane to było wolniejszym rytmem przemian kulturowych na terenach górskich ${ }^{28}$ oraz dużym przywiązaniem do tradycyjnego stroju ludowego, który spełniał wiele funkcji. Prócz oznaczania choćby stanu cywilnego, zawodu, czy wieku identyfikował on daną jednostkę z grupą ${ }^{29}$. Im silniejsze więzi łączyły członka grupy ze zbiorowością, do której należał, tym mocniej podkreślał on własną przynależność poprzez strój. Utrzymanie się tradycyjnego ubioru łemkowskiego przez tak długi okres może świadczyć o istnieniu trwałej, tradycyjnej więzi grupowej.

Pod koniec lat trzydziestych XX w. w związku z silniejszymi wpływami nurtu narodowo-ukraińskiego nastąpiły pewne zmiany w sposobie zdobienia stroju. Zaniepokojony tą sytuacją "Ilustrowany Kurier Codzienny” w sposób przesadny interpretowal ten fakt widząc w nim przejaw upolitycznienia Łemków: „Dzisiaj na Łemkowszczyźnie, głównie we wsiach powiatu nowosądeckiego przeważają i to nie tylko wśród młodzieży, ale i starszych gospodarzy i kobiet, koszule bogato przystrojone krzyżykowymi wyszywankami. Te wzory charakterystyczne są dla mieszkańców małopolskiego Podola, zapalonych Ukraińców, którzy swymi wpływami zalać chcą łemkowskiego Pogórzanina. (...) A Łemko to typ spokojnego człowieka, element bardzo podatny... Zmiana regionalnego stroju na Łemkowszczyźnie na ukraiński ład (...) to tylko z pozoru błaha sprawa, ma ona głęboki polityczny oraz narodowy sens"30.

Rusini Łemkowszczyzny mocno związani byli z rodzinną ziemią, a więź z terytorium przekraczała często granice lokalności. Wyrazem przywiązania do „ojczyzny prywatnej" $z$ jednej strony, $z$ drugiej zaś przykładowo do terytorium całej Ukrainy ${ }^{31}$

tym samym tedy prawem można by ich nazwać Lemkami, Nemkami, Leżkami. Wypadałoby się tylko postarać o historię dla narodu Nemków i Leżków", cyt. za M. Lesiw, Ukrajins ‘ki howirki w PNR, „Nasze Słowo” 1987, nr 11. Por. też: R. Brykowski, Lemkowska architektura cerkiewna w Polsce, na Stowacji i Rusi Zakarpackiej, Wrocław 1986, s. 12-13.

Tenże, Strój Łemków (w:) Nad rzekq Ropa....op.cit., s. 165.

29 . 163-232

31 Należy podkreślić, że w spoleczności łemkowskiej do dzisiaj istnieją dwa modele tożsamości. Jeden $z$ nich nawiązuje do poczucia wspólnoty z narodem ukraińskim, drugi natomiast próbuje kształtować odrębną wspólnotę w ramach tzw. narodu karpatoruskiego. 
był list Sofi Seniuś nadesłany do redakcji „Naszego Łemka” w 1937 r., w którym czytamy: „Wspomnienia związane $\mathrm{z}$ rodzinną wsią tworzą taką nierozerwalną więź, że gdzie byśmy nie poszli (...) wspominamy ją. Ten kto kocha rodzinną wieś, kochać potrafi również i swój rodzinny kraj oraz naród swój, a jak przyjdzie czas i potrzeba

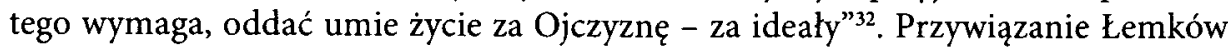
do rodzinnej ziemi przejawiało się również w twórczości ludowej na emigracji, której początek datuje się na koniec XIX wieku. Niechęć do zmian i przywiązanie do tradycji przejawiało się także w organizacji życia emigracyjnego. Wszystkie wartości jakie istniały w Starym Kraju przeniesione zostały na grunt Nowego. Religia nadal pozostawała głównym łącznikiem zbiorowości etnicznej Łemków. Wiara ojców została złączona z językiem ojców, w którym się modlono, rytualny charakter języka występował w napisach cmentarnych. W celu podtrzymywania więzi grupowej stworzono w USA „Lemkiwskij Komitet” z organem „Lemko" (1922) oraz "Lemko-Sojuz” (1929), który rozpoczął wydawanie gazety w lemkowskim dialekcie "Karpatska Ruś". Były to organizacje założone przez zwolenników kierunku moskwofilskiego, prowadzących działalność o charakterze antyukraińskim ${ }^{33}$. Dowodem tego jest następujący fragment zamieszczony w styczniowym numerze „Lemka” z 1928 r. (Nowy York): „Rusin może pogodzić się z Polakiem, Niemcem jak równy z równym. Ale nigdy nie może pogodzić się z Ukraińcem"34.

Organizacje wyżej wymienione spełniały jednak pozytywną rolę w tworzeniu życia kulturalnego na obczyźnie. Przyznać należy także, iż pierwsze organizacje teatralne, muzyczne czy taneczne tworzone były przy cerkwiach spełniających rolę koordynatora działalności kulturalnej na emigracji. Przedstawienia nawiązujące treścią do dorobku kultury tradycyjnej ze Starego Kraju odbywały się po nabożeństwie niedzielnym, stwarzając tym samym możliwość bliższego poznania się członków zbiorowości. Spotkaniom tym towarzyszyły wspomnienia z życia na ziemi ojców.

Pomijając działalność propagandowych nurtów czy to na emigracji, czy w kraju stwierdzić należy, iż wiele faktów przemawia za jednością kulturową Łemkowszczyzny z Rusią Kijowską. Równocześnie nie można zaprzeczyć istnienia swoistych, właściwych sobie cech $w$ tradycji kulturowej Łemków. Wynikało to $z$ pewnej izolacji

32 I tak np. emigranci w USA wyraz swej tęsknocie za rodzinną wsią dali w słowach pieśni: „Tylawa, Tylawa okruhłe sełeczko, jak ja tia ne wydżu, bołyt mia serdeczko", cyt. za „Nasz Łemko” 1937, nr 23, s. 11.

33 Działalność moskwofilów na emigracji nie pozostała bez wpływu na życie w kraju. Przykładowo na początku 1934 r. stworzyli oni we wsi Łabowa (pow. Nowy Sącz) emigracyjny komitet, który poczynił próby przesiedlenia Lemków na wolne ziemie Syberii. Twórcy powyższego projektu zwracali się nawet $w$ tej sprawie do rządów Polski i Związku Radzieckiego. Równocześnie jednak w latach 30-tych wzmacniały się wpływy narodowców-Ukraińców. Dowodem tego mogą być koncerty wykonywane przez Łemków z powiatów: leskiego, sanockiego, krośnieńskiego, jasielskiego, grybowskiego, gorlickiego i brzozowskiego, z których dochód przeznaczono na oświatę narodową na Łemkowszczyźnie. Por. „Nasz Łemko” 1934, nr 21, s. 2 i s. 4.

34 „Annały Switowoji Federacji Łemkiw”, cz. 2, 1975, s. 94. 


$$
2
$$

